\title{
Internal and External Dynamics of the Munich Film and TV Industry Cluster and Limitations to Future Growth
}

\author{
Harald Bathelt \& Armin Gräf
}

\begin{abstract}
Version Post-print/accepted manuscript
Citation Bathelt, H., \& Graf, A. (2008). Internal and external dynamics of the (published version) Munich film and TV industry cluster, and limitations to future growth. Environment and Planning A, 40(8), 1944-1965.
\end{abstract}

Copyright / License

Publisher's Statement

The version of record [Bathelt, H., \& Graf, A. (2008). Internal and external dynamics of the Munich film and TV industry cluster, and limitations to future growth. Environment and Planning A, 40(8), 19441965.] is available online at: http://epn.sagepub.com/content/40/8/1944 [doi: 10.1068/a39391]

Always cite the published version, so the author(s) will receive recognition through services that track citation counts, e.g. Scopus. If you need to cite the page number of the TSpace version (original manuscript or accepted manuscript) because you cannot access the published version, then cite the TSpace version in addition to the published version using the permanent URI (handle) found on the record page. 


\title{
Internal and External Dynamics of the Munich Film and TV Industry Cluster and Limitations to Future Growth
}

\author{
Harald Bathelt \\ University of Toronto, Department of Political Science, \\ Sidney Smith Hall, 100 St. George Street, Toronto Ontario, Canada M5S 3G3, \\ E-mail: harald.bathelt@utoronto.ca, \\ URL: http://www.harald-bathelt.com \\ and \\ Armin Gräf \\ Faculty of Geography, University of Marburg; \\ Mailing address: Saalburgstrasse 3, 60385 Frankfurt, Germany, \\ E-mail: armin.graef@gmx.net
}

Paper submitted to Environment and Planning A 


\section{Internal and External Dynamics of the Munich Film and TV Industry Cluster and}

\section{Limitations to Future Growth}

Abstract. This analysis uses the case of a seemingly successful industry cluster, i.e. the film and TV industry in Munich, to demonstrate that deficits in the structure of social relations can impact a cluster's growth potential. In the post-World War II period, Munich grew into a national centre of these industries in Germany due to the introduction of private/commercial $\mathrm{TV}$, national entry barriers and a supportive institutional infrastructure. The recent advertising crisis and the dissolution of the Kirch Group have, however, reinforced already existing internal dilemmas and contradictions. We suggest that the growth prospects of this industry are limited due to a lack of reflexive, interconnected communication and interaction patterns. In conceptual terms, we apply a model which emphasizes that local interaction or 'buzz' in clusters and interaction with external firms and markets through trans-local or global 'pipelines' create reflexive dynamics. Based on this conception, participatory observation and semi-structured interviews were conducted with 65 Munich firms, as well as planners and media experts from the region. The results indicate that the regional, national and occasional international project networks have had a smaller impact on the Munich film and TV industry than expected. Our investigation provides evidence that the cluster's structure of social relations is relatively weak. Internal networks which could drive creative recombination and innovation are underdeveloped and linkages with external markets which could provide substantial growth impulses to the region are lacking. We argue that this structural weakness limits the potential for future growth. 


\section{Introduction: Genesis of the Munich Film and TV Industry Cluster}

As has been shown in recent work, media industries, particularly film and TV production, can become important drivers of urban economic growth (Scott 2000, Krätke 2002). In most industrialized countries, important centres of these industries have developed which generate high incomes and create highly-skilled jobs for those embedded in the project ecologies of these industries. By drawing on the case of Munich, a well-established centre of the film and TV industry in Germany, this paper presents a seeming success story. At closer investigation, however, this industry has substantial problems. Although Munich is the most important centre of the film and TV industry in Germany, our investigation provides strong evidence that its structure of social relations is relatively weak. Internal networks which could drive creative recombination and innovation are underdeveloped and linkages with external markets which could provide substantial growth impulses to the region are weak. We argue in this paper that this structural weakness limits the potential for future growth of this industry.

This vulnerability is by no means obvious, however, as the Munich film and TV industry has a long tradition. While Berlin was the undisputed centre of film making until the end of World War II, Munich established itself as an important production site for high-quality feature films (Horak 1996). After World War II, Munich developed into the dominant location of the newly established German film and TV industry, challenged only by Cologne, Berlin and Hamburg (Gräf and Matuszis 2001, Gräf, Hallati and Seiwert 2001, Mossig 2006, Ernst \& Young 2006). According to the sales tax statistics, the film and TV industry in the city and county of Munich consisted of a total of 2,845 establishments (Table 1) and had sales of 6.47 billion Euros in 2004 (Table 2). Munich accounted for more than $15 \%$ of all establishments and employees and over $30 \%$ of all sales in this industry in Germany (Krätke 
and Scheuplein 2001, Ernst \& Young 2006). As shown by Gräf (2005), Munich's film and TV industry developed into a fully-fledged industry cluster, characterised by well-developed vertical, horizontal and institutional cluster dimensions (see, also, Industrie- und Handelskammer für München und Oberbayern and Landeshauptstadt München 2003).

The reasons behind this growth of the Munich film and TV industry are closely related to a set of favourable conditions which formed in the post-World War II period. First, the reconstruction of the German film and TV industry was not focussed on its former core Berlin due to the geographical isolation and unclear future of the city at that time. Munich, which was already an important media location in the early 20th century with activities in fine mechanical, optical products and motion picture production (Biehler, Genosko, Sargl and Sträter 2003), benefited from Berlin's uncertain future. Second, the growth of the Munich cluster benefited from the relative 'closedness' of the German TV market which can also be observed in other national TV markets (e.g. De Laurentis, Cooke and Williams 2003). Substantial entry barriers exist for foreign competitors due to specific regulatory mechanisms, language barriers and other cultural factors favouring interaction between firms/freelancers at a national level. Third, the growth of Munich's film and TV industry cluster was also based on traded interdependencies, related to low transaction costs and economies of scale. Film and TV producers, for instance, were able to exploit existing infrastructure and build upon large pre-existing project networks of media specialists. Fourth, a unique institutional structure developed parallel to this growth consisting of funding and training organizations, such as the FilmFernsehFonds Bayern (FFF), Bayerische Akademie für Fernsehen (BAF) and Hochschule für Fernsehen und Film München (HFF). These supported the growth of the cluster relative to other German media locations. Finally, Munich received important growth impulses due to the introduction of the so-called dual broadcasting system in 1984, through which private/commercial TV was established (van den Berg, Braun and van Winden 2001). 
These factors help explain why Munich developed into a leading national centre of film and TV production. They do not help us understand, however, the reasons as to why the cluster has remained of limited importance in international terms. With the economic recession in 2001, the negative effects of the lack of strong linkages with media markets and locations outside of Germany became quite obvious. Further, shrinking advertising in the manufacturing sector not only hit the advertising industry ${ }^{1}$ (Jentsch 2004) but also had a severe impact on private broadcasters. In addition, the bankruptcy of the Kirch Group, a fully integrated media group headquartered in Munich, caused disarray in the film and TV industry. Overall, these problems are clearly reflected in the development of sales figures. From 2000 through 2004, sales in the Munich's film and TV industry decreased by $19.2 \%$, from 8.01 billion Euros to 6.47 billion Euros (Table 2).

Using this as a point of departure, this paper analyses local and non-local communication patterns and market linkages in the Munich film and TV industry cluster. The hypothesis developed in this paper is that the growth prospects of Munich's film and TV industry are limited due to a lack of reflexive, interconnected communication and interaction patterns. We argue that the structure of social relations in this industry is not well developed despite the region's importance as a national hub of these industries. Based on a conception which emphasizes that the growth of clusters depends upon the reflexive dynamics of internal and external knowledge flows, our goal is to draw conclusions about growth prospects of the Munich film and TV industry by looking at the structure of social relations in local vs. nonlocal interaction (Bathelt, Malmberg and Maskell 2004, Bathelt 2004, 2005). Although it would be tempting to suggest that the film and TV industry will continue to grow once the

\footnotetext{
${ }^{1}$ Between 2000 and 2003, sales in the Munich advertising industry decreased by $41.5 \%$ from 2.12 billion Euro to 1.24 billion Euro (Table 2).
} 
effects of the advertising and Kirch crises are overcome, the results of this research provide a different perspective. We will show that the actual problems of the Munich film and TV industry are rooted more deeply in the existing structure of social relations.

The structure of the paper is as follows. In section 2, we discuss the conceptual basis drawing on a knowledge-based model of clusters. We briefly outline the core ideas of this model emphasising the interrelationship between a cluster's local interaction or 'buzz' and interaction through global or trans-local 'pipelines'. This is presented as a substantive extension of traditional regional multiplier models. Section 3 provides an overview of the methodology and empirical basis of the paper. Section 4 gives an overview of dilemmas and crises affecting Munich's film and TV industry as a starting point for further analysis. Section 5 unravels the region's internal interaction and communication patterns, emphasising the effects of fragmented communication while section 6 and 7 investigate the barriers of access to international markets, inter-sectoral linkages and additional finance. Finally, conclusions will be drawn in section 8 regarding the structural limitations of growth in the Munich film and TV industry.

\section{The Reflexive Relation of Local Buzz and Global Pipelines in Clusters}

In order to understand the structure of social relations in the Munich film and TV industry, we have applied a knowledge-based conception of clusters which emphasizes the complementarity of local and trans-local or global interaction and communication patterns. This conception acknowledges that closely intertwined regional concentrations of firms from a particular value chain, together with their supporting suppliers and service providers, continue to attract other firms of that chain (Porter 1990), despite globalization tendencies in economic production and trade. A considerable part of economic production appears to be 
located in such clusters. The conception used in this paper integrates different arguments to overcome the rigidities which exist in some of the literature on industrial agglomerations. This literature over-emphasises the importance of close networks between local agents while neglecting the significance of global linkages in terms of access to markets, technologies and creative pools of ideas.

It appears misleading to assume that clustering generally results in strong localized transaction networks. In fact, it has been pointed out (e.g. Oinas 1999, Tracey and Clark 2003, Amin and Cohendet 2004) that existing evidence for the existence of intensive material linkages and input-output relations within clusters is relatively weak. First, it has been recognised that it is not sufficient to focus on traded interdependencies to explain the continued growth of clusters but to apply a knowledge-based conceptualization (Maskell 2001, Malmberg and Maskell 2002, Pinch, Henry, Jenkins and Tallman 2003, Bathelt, Malmberg and Maskell 2004, Bathelt 2005). Second, strong linkages with external markets and global knowledge flows have been identified as being critical to a cluster's economic performance (e.g. Bresnahan, Gambardella and Saxenian 2001, Amin and Cohendet 2004, Owen-Smith and Powell 2004). Both aspects are central to the cluster model presented in this paper.

This conception argues that local interaction or 'buzz' and interaction through trans-local or global 'pipelines' create a dynamic process of learning, knowledge production and innovation which is key to understanding a cluster's success. Co-location and face-to-face contacts within a cluster give rise to a particular information and communication ecology or local buzz (Storper and Venables 2004, Bathelt, Malmberg and Maskell 2004). This buzz consists of specific information flows and continuous updates, as well as intended and unintended learning processes and the application of the same interpretative schemes and mutual understanding of new knowledge and technologies. Messages, information, news, rumours, 
gossip and trade folklore are automatically received by those who are located in the cluster and who participate in its various social and economic spheres (Uzzi 1997, Grabher 2002a, 2002b). Being located in the same region also enables firms to understand the local buzz in a meaningful way because co-location stimulates the development of a particular institutional structure shared by those who participate. This buzz also becomes part of local transaction networks and influences them. Although its existence does not depend on the particular set of actors in the cluster, its precise nature is necessarily shaped by the agents involved. This explains why the buzz observed in one cluster likely differs from that which exists in other clusters.

Despite the importance of local network relations, it has been contended in recent work that global interactions or pipelines are often at the core of individual and collective competitiveness of cluster firms (Owen-Smith and Powell 2004, Bathelt, Malmberg and Maskell 2004). In contrast to the type of communication and interaction occurring inside clusters, the knowledge flows in trans-local pipelines have a different structure. These linkages are targeted towards a pre-defined goal aimed at extending a firm's knowledge base. They have to be created and require particular investments. This involves a high degree of uncertainty. The resulting interaction is thus greatly impacted by the degree of trust that exists between the pipeline partners. Often new trust has to be built which is a timely and costly process.

In this line of thought, the particular combination of local buzz and trans-local pipelines is believed to generate a reflexive process of knowledge creation within a cluster which provides the potential for enhanced learning capabilities and future economic growth. The local buzz benefits from trans-local pipelines through which additional subcontracts and new knowledge are pumped into the cluster. Pipelines which are open or 'leaky' function as sprinklers which 
support the diffusion of information within the cluster (Owen-Smith and Powell 2004). This stimulates additional buzz and serves as a basis for further product innovation and differentiation. Intensive local buzz helps firms to distinguish important from less important developments and enables them to recognize the significance of trans-local pipelines and acquire knowledge about the establishment of new pipelines.

This model of local buzz and global pipelines can be interpreted as a knowledge-based extension of conventional regional multiplier or export-base models (see Bathelt 2006). The latter models argue that economic growth in a region can be triggered if export activities to other regions and nations are expanded (e.g. Lloyd and Dicken 1972, Schätzl 1978). Following a simple multiplier logic, it is assumed that growing exports to other regions will create additional income in the region. This additional income will be partially spent for the consumption of other locally produced goods and, thus, produce growth even in those regional sectors which are not engaged in exports. This will result in further growth through consecutive rounds of consumption in the future. Over time, a regional multiplier effect will occur, the magnitude of which depends particularly on marginal consumption and import rates. In short, the regional multiplier approach views export activities as being the key factor influencing the growth of a regional economy. A problem of this approach is, however, that it treats regional and national boundaries in much the same way, neglecting the importance of institutions and agents. Like other neoclassical models, it does not capture the real intentions and strategies of actors, the effects of their interaction and the social processes behind learning and innovation. Overall, the understanding of regional growth processes remains incomplete.

The buzz-and-pipeline cluster approach can be viewed as a substantial extension of regional multiplier models (Bathelt 2006). In this approach, external resources enter the cluster and 
stimulate rounds of recombination through which innovation and growth impulses result. By way of trans-local networking, these, in turn, have an impact on other regions. This approach conceptualizes a reflexive process by including feedback loops of knowledge creation which result in increased innovation and competitiveness. It overcomes weaknesses of traditional multiplier models by applying an actor perspective and building upon the social relations at the core of economic processes. Subsequently, we will apply this conception to the context of the Munich film and TV industry to analyse the structural problems underlying communication and interaction processes in this cluster.

\section{Methodology}

This paper is based on extensive fieldwork, including explorative interviews, discussions with experts, field observations and semi-structured interviews which were conducted between 2002 and 2004 during three research trips to Munich. One of the authors worked for three months with a major company of the Munich film and TV industry, which operates several facilities spread out through the city, to gain practical experience in this business. This involved active and passive participation in film shootings, as well as in the stages of studio preparation, planning and contract negotiation. In this phase, open, unstructured observations were made and recorded. This served as an important basis for the exploration of the value chains in the industry which rely on a project-based organisation. Figure 1 shows an example of a value chain of a fictional TV series and the various tasks which have to be performed by different agents throughout the course of a project. Although the various tasks performed follow a sequence of pre-production/content production, project development/initiation, production, post-production and distribution, this is by no means a linear process (Gräf 2005, 
Mossig 2006). The social division of labour involves substantial feedback processes and ongoing adjustments throughout almost the entire duration of the project.

Although film and TV projects usually involve non-local agents and do not fully rely on the local labour market, industry clusters typically emerge as agglomerations of skills and tasks of the value chain. This is also the case in Munich. Another interesting feature is that existing value chains differ substantially between different $\mathrm{TV}$ and film genres, generating a fragmented labour market (Gräf 2005). Of course, there are also clear differences between the film and the TV production chains in terms of markets, regulatory affairs, governance mechanisms, financing and distributions channels. Even though substantial overlap in the labour market and supplier networks could be expected as the structure of individual tasks is often similar, segmentation tendencies appear through which value chains hardly overlap. As a result, media specialists tend stay within a particular genre throughout most of their career. The analysis presented, therefore, differentiates between film and TV production, as well as public and private broadcasting.

Overall, 65 semi-structured interviews were conducted with actors from different value chains in the film and TV industry and other media institutions such as specialized industry associations and academies (Table 3). In addition, information was acquired through interviews with media experts and planners in the region. While the size of the companies interviewed varied significantly, most interviews were conducted with small and mediumsized firms (Table 4). This is representative of the structure of the film and TV industry cluster in Munich, which is largely dominated by the latter type of firms (Biehler, Genosko, Sargl and Sträter 2003). On average, interviews took about 60 minutes. They were recorded on tape, transcribed and condensed into a structured data matrix for further analysis. Although the firms interviewed were not selected randomly, the results from this research can still be 
viewed as being representative of the important structures and trends in the Munich film and TV industry cluster, due to the large number of interviews conducted.

Our paper primarily draws on 48 of these interviews which were primarily conducted between August 2003 and August 2004 with core actors of the different film and TV production chains, i.e. with producers and post-production executives. The firms and individuals included were chosen based on the previous analysis of value chains (Figure 1). Although we recognise that the industry also involves a large number of freelancers, these were not the major focus of our study. We selected agents which have both extensive knowledge of and exercise control over substantial parts of the production process. It turned out that particularly the executives of production and post-production firms were appropriate interview partners because they also make the decisions about internationalization processes and international cooperation. The questions asked were split up into five sections to acquire information about the structure of social relations in the Munich film and TV industry cluster: (i) firm structure and history, (ii) interaction with local partners and institutions, and advantages of local networking, (iii) contacts with creatives and technical specialists from other regions and nation-states, and access to international markets and finance, (iv) linkages with related sectors, and the development towards an integrated entertainment sector, (v) growth perspectives in the future. In order to measure the effects of local influences and compare them with non-local influences from other German and international media locations we asked respondents to describe the nature, frequency and importance of these linkages and evaluate their significance. $^{2}$

\footnotetext{
${ }^{2}$ In order to draw conclusions about the quality and quantity of local buzz and trans-local pipelines, we asked questions about the nature of information flows and network relations with other agents. For instance, we asked with whom the interviewees cooperated in their recent projects; where these people were located; what
} 


\section{Origins of the Dilemmas and Crises of Munich's Film and TV Industry}

This section shows that the genesis of the Munich film and TV industry cluster in the postWorld War II period was neither unproblematic nor free of conflict. The growth of the cluster since the $1980 \mathrm{~s}$, which was primarily driven by the introduction of commercial/private TV and the respective growth of the Kirch Group, gave rise to initial dilemmas. These were reinforced by the advertising crisis and the dissolution of the Kirch Group at the turn of the Millennium. Although the focus of this paper is not to analyse the effects of these crises, we use this as a starting point for further empirical analysis.

The Kirch Group was originally established and led by one person, i.e. Leo Kirch. He launched his successful media operation in the late 1950s by buying and trading film rights. After the introduction of the dual broadcasting system in 1984, Kirch started up, acquired or integrated several broadcasters, such as Sat.1, ProSieben, the pay TV channel Premiere, Kabel1, the sport channel DSF and the news channel N24, as well as production firms (e.g. ndF - neues deutsches Fernsehen) and other related activities (Frankfurter Rundschau 2002a, 2002b). The vertically and horizontally integrated Kirch Group developed into one of the dominant actors of the German film and TV industry. A central part of the Kirch Group and an important basis of the Munich TV industry was the ProSiebenSat.1 Media AG, a conglomerate of several TV stations with total sales of 2.16 billion Euros and about 3,200 employees in 2000 (Kurp 2005). After the dissolution of the Kirch Group, the ProSiebenSat.1

\footnotetext{
kind of information was exchanged; how often contacts were made and how important they were; whether this included face-to-face meetings; whether information was also exchanged in a less planned manner and how; which funding sources were approached and why; which other regular and occasional contacts existed in the media sector; how these contacts differed between people in different parts of Munich, Germany and other countries and the like. The respective answers enabled us to distinguish high- versus low-quality and frequent versus rare information and knowledge flows at different spatial scales.
} 
Media AG was acquired by the US media billionaire Haim Saban (Frankfurter Allgemeine Zeitung 2003b). ${ }^{3}$

As a result of this growth, many production and post-production firms (e.g. MET, TV Werk) located their facilities to Munich to be close to the broadcasting services which were their main customers. Consequently, they developed close contacts with local broadcasters. As Gräf (2005) has shown, local suppliers and service firms still play a decisive role in the project networks of the Munich broadcasters. To be able to make quick adjustments, coordinate production and remain flexible, they largely rely on regional partners in their projects. The development has, however, also indicated tendencies of stagnation since the late 1990s. The cases of film studios, such as Plazamedia and the Bavaria Filmstudios, which increasingly rent out studio space to low-budget TV shows and series, indicate that the TV production networks have begun to face a 'creativity dilemma', similar to that encountered in the Leipzig advertising industry (Jentsch and Bathelt 2007). On the one hand, they need to be more creative and innovative to tap into new markets and win new customers. On the other hand, they have introduced cost-cutting measures leaving few resources for innovative thinking.

The post-World War II growth in the film sector was less spectacular even though movie production also benefited from the growing cluster dimensions. The genesis of this sector in the early 20th century was related to the successes of early start-ups (Biehler, Genosko, Sargl and Sträter 2003), such as the producer of camera equipment Arnold \& Richter Cine Technik

\footnotetext{
${ }^{3}$ By 2006, Saban had successfully cut costs and restructured the former ProSiebenSat.1 Media AG. After plans failed to sell the firm to the German Axel Springer AG, due to an objection of the German Cartel Office, Saban started an auction in October 2006 to find a new buyer (Frankfurter Rundschau 2006a, 2006b). The fact that the future owner will most likely be a foreign media conglomerate has created debate about the sense of German cartel laws (Schmitz 2006).
} 
in 1917 (today: ARRI) and the movie theatre and production firm Münchener Lichtspielkunst AG in 1919 (later: EMELKA; today: Bavaria Film). Compared to other media centres in Germany, the city hosts a unique concentration of investment companies and financial institutions which support motion picture production, including subsidiaries of the Hollywood Majors, German distributors (e.g. Constantin) and one of the most important public film funds in Germany, i.e. the FilmFernsehFonds Bayern. Despite this, the film industry has begun to show tendencies of stagnation in recent years.

This is related to the fact that international recognition of Munich's motion picture industry is limited. Major successes, such as 'Das Boot', have been the exception. Most motion pictures produced in recent years were primarily directed towards the German market and did not receive international attention. An 'identity dilemma' has developed while the pre-World War II tradition of film production disappears. This tradition is still being used to promote the city as an international media location. At the same time, however, TV production has become the core business in Munich and resources and infrastructure have increasingly specialised to serve private/commercial broadcasters. Berlin-Babelsberg, in contrast, has gone another route and tries to promote itself as the coming centre of motion picture production.

At the turn of the Millennium, crisis tendencies in Munich became more obvious. The Kirch Group ran into severe financial difficulties due to a number of structural problems and failures. These included false growth predictions in pay TV, financial losses of private broadcasting channels, the acquisition of overpriced film rights for sports events, overly hierarchical decision-making centred on Leo Kirch and a tendency towards closed, over-integrated group networks. As a consequence, many people lost their jobs and numerous bankruptcies, restructuring activities and management buy-outs occurred when the Kirch Group declared bankruptcy and was eventually dissolved (Frankfurter Allgemeine Zeitung 2002, 2003a). 
This happened at a time when a general reduction in advertising expenditures hit the German economy. This advertising crisis severely impacted the activities of the private broadcasters in Munich (Frankfurter Allgemeine Zeitung 2003b). It caused many employees to be laid off and restructuring activities to be undertaken within the broadcasters. Risky experiments involving new TV formats were stopped and contracts for the production of new TV films cut to a minimum. Instead of producing new TV films and programs with an innovative content, low budget TV series and shows were extended (e.g. 'Big Brother', quiz and talk shows).

Production firms which were closely tied to the private broadcasters suffered most from the crises. They were under heavy cost pressure, as the number of film and TV productions decreased and the broadcasters reduced prices for external production contracts. Through this situation, many producers were caught in a vicious circle. They focused on cost efficiency and high productivity instead of trying to come up with new, creative ideas which could have supported them in getting access to new markets outside the Munich film and TV industry. The dissolution of the Kirch Group also caused a growing number of production companies to be spun out into the market of independent film production, thus creating more competition in this segment. As a result, markets became tighter and production firms began giving up their specialisation in particular segments. Instead, they began to diversify. Producers of movies also started to subcontract work to Eastern Europe to take advantage of low-cost production in these countries (i.e. Czech Republic, Baltic States). In addition, it became more difficult for independent producers and film distributors to obtain finance for new projects from banks, due to the so-called Basel II agreement which will demand stricter requirements and greater security for granting bank loans (Nörr, Stiefenhofer and Lutz 2004).

In the public broadcasting sector, the negative effects of these crises were less visible. In contrast, the dissolution of the Kirch Group even opened up new opportunities. Licensing 
prices for sports events and production services, as well as for the utilization of the former Kirch film library, dropped. In addition, it became easier for public broadcasters to hire specialised personnel. While these broadcasters were previously viewed to be somewhat outdated and hierarchical, specialists were now pleased with the relative employment stability in this segment.

\section{Local Communication and Information Flows}

It would be tempting to speculate that the Munich film and TV economy will continue to grow once the effects of the Kirch and advertising crises are overcome. However, as will be argued below, there are deeper structural problems which have developed in the film and TV sector which serve to block off regional knowledge flows and opportunities for recombination

to develop new film and TV formats. This section focuses on the analysis of internal communication patterns and information flows to explore this problem. Although we can assume that the networks of communication and information flows in Munich are more diversified than in many other German media locations (e.g. Krätke 2002, Bathelt 2005), this is mainly due to the broadly diversified vertical and horizontal dimensions of the Munich cluster and the long value chains which exist (Mossig 2006). We found strong evidence, however, that the local buzz is not as rich as one would expect due strong segmentation and fragmentations tendencies.

\section{Segmented Value Chains}

The relatively low density of local communication and information flows is related to the fact that the existing value chains are extremely segmented (Gräf 2005). This segmentation occurs along three dividing lines, i.e. by media branch, TV format and broadcasting group. First, 
despite the use of similar technologies and tasks, different contexts of motion picture production exist between different media branches (advertising, movie and TV production) which are associated with different problem-solving activities and routines. Interaction between these branches is thus limited. Second, different TV formats (film, documentary, series and show) require specific technical skills and differ in terms of creativity, organization and sequence. This also results in divided value chains. Third, segmentation is particularly strong between private and public broadcasting groups.

There are two broadcasting groups in the Munich film and TV industry which have developed their own producer and supplier networks, i.e. the Kirch Group (including ProSieben, Sat.1, Kabel1, Premiere) and the public broadcasting services (Bayerischer Rundfunk, regional ZDF-Studio), including the Bavaria Film network. These networks are mutually exclusive and could be classified as quasi-integrated, similar to the network configuration described by Leborgne and Lipietz (1991). Although the firms in these broadcasting networks are often independent in terms of ownership, their decision making processes are not. They meet to make collective decisions and conduct business with each other, locking out firms from other broadcasting group networks. One respondent described this as follows: "We have only found networks in conjunction with these big conglomerates. I would say the old Kirch Media. Yes, with all the associated companies when Leo Kirch invited 250 managers to his house up on the hill ..., sealed off from the outside world for three days. Other external producers were not invited. They didn't find out much about these meetings because everything was kept quiet, while the people inside, of course, only thought about maximizing profits. The same can be said for Bavaria Film and its relation with public broadcasters. Many of the activities behind the scenes are about wheeling and dealing. It's a network of its own. As a publicly-owned firm, it is understandable that I would primarily go to my own subsidiaries because this is 
where my money is. And this is the way it is. There are networks out there which we can't really get into.”

The result of these segmentation tendencies was the development of parallel project networks which were fairly closed and did not have much overlap. Each broadcasting group relied on an almost proprietary set of script writers, productions firms, actors, camera men and the like. Due to segmentation and specialisation tendencies, individual agents had few opportunities to shift between different branches of the industry throughout their career. We can assume that this structure has limited possibilities for the development of creative ideas, as pointed out by Vinodrai (2006) in a different industry context.

There are some tendencies, however, that indicate this could partially change in the future. First, we encountered some firms and freelancers who do not clearly belong to any particular broadcasting group (e.g. MET, TV60). They form a kind of network themselves, as one interviewee mentioned: “There are producer networks which do not belong to these closed circles but they know quite well what's going on because of the networking which takes place between different levels. ... You always work with the same people and exchange your ideas with these same people. And you just get to know everyone. Contacts are generally maintained over time. ... Through this, information flows are kept alive.” In the future, such practices could become more widespread in Munich stimulating open information exchange and the development of new ideas. Second, the exclusive character of the networks of the broadcasting groups has begun to dissolve, since production companies, such as ndF, try to conduct business with all types of broadcasters and cover the whole market. Core actors, such as the Bavaria Filmstudios, could play an important role in the process of creating more diversified, variegated project networks because they already have contracts with each of the groups. Thus far, however, they do not mediate between the groups. 


\section{Fragmented Communication Patterns in Different Localities}

Overall, firms in the Munich film and TV industry seemingly benefit less from local buzz than expected. Many interviewees mentioned that they had relatively little contact with others in their industry and rarely go to trendy bars and cafes which are well-known as meeting places for the media business. They mentioned that they primarily depend on personal networks which they themselves or their close colleagues established to get new information about the industry and its market. Information exchange with these colleagues takes place on a daily basis in the office. Although transaction and project networks are impacted by such communication, general information exchange is neither fully systematic nor ubiquitous. It seems exceptionally strong within particular 'communication islands' and is usually limited to the respective office spaces. It does not easily spread to other localities and circles. This is because unintended, less organized meetings and interactions, where diverse information flows between different organizations can occur, are less important according to our interviewees. Overall, this creates fragmented communication patterns. As indicated below, even within the various cores and localities of the Munich film and TV industry, social practices exist which limit information exchange and knowledge flows.

(a) Media Park Unterföhring: Along a stretch of several hundred meters close to the S-Bahn station Unterföhring, there is a large concentration of media firms, including ProSiebenSat.1 Media AG, Bayerischer Rundfunk and the Bavaria Filmstudios (Figure 2). Despite their close proximity, there is hardly any interaction between the employees of these organizations. The firms' policy is to fully concentrate on themselves and ignore their neighbours. Employees from other firms are not even allowed to show up for a coffee or lunch break in their dining halls and cafes. In-depth information exchange in the Media Park Unterföhring is thus nonexistent. The only strong local linkages which exist are those between the broadcasters and 
some of the production firms which produce for them on a virtually exclusive basis (e.g. between Bayerischer Rundfunk and Megahertz, or between ProSieben and SZM). The Media Park Unterföhring is characterized by a high degree of anonymity and lacks public meeting places, such as street cafes or restaurants, where individuals can interact. This structure has some similarities with the 'distanced neighbour paradox' identified in Leipzig (Bathelt 2005). Institutions, like the Bayerische Akademie für Fernsehen, which is located around the corner, could act as a place for information exchange but have so far failed to encourage more intensive interaction and to mediate between the different broadcasters and production firms.

(b) Geiselgasteig: The Bavaria Filmstadt in Geiselgasteig is also characterized by a large concentration of TV and film-related firms, including smaller broadcasters (i.e. RTL II, Tele 5), numerous studios for film and TV production and shows (i.e. Bavaria Filmstudios), Bavaria Filmproduktion, which is closely related with the public broadcasters, and other independent film producers (Figure 2). At first glance, Geiselgasteig appears to be more open than Unterföhring. There are meetings places, such as cafes and places where people from different firms can sit together and have lunch. Further, people meet on the streets and chat, as one interviewee mentioned. The people interviewed in Geiselgasteig also confirmed that this location was more conducive for communication and interaction between individuals than Unterföhring. However, they also pointed out clear limitations of such communication similar to those in the Media Park Unterföhring. Firms, such as RTL II and Tele 5, are often insular in their activities, ignoring the existence of the others.

(c) Communication islands: There are, however, small communication islands in different parts of Munich, such as TV Werk, parts of Schwabing (Figure 2) and, at an earlier stage, the former Stetten barracks and the Lodenfrey area where intensive, open communication patterns have developed (Gräf 2005). Such areas appear trendy and 'hip' to media people. These are 
places where established ideas are constantly combined with new ones, existing routines challenged by new combinations and creative ventures tested. It almost seemed as if these communication islands were like homes to the employees, and not their workplaces. At the same time, our interviewees indicated that these locations are fairly closed and do not interact as intensively with other areas in the respective industries in Munich.

(d) Differentiation between media centres in Germany: Segmentation tendencies can also be identified in the relation with other German media centres. This is especially obvious in the area of TV production. Although most TV films, series or shows involve agents from other German media centres and even though joint funding of films through Länder requires that substantial inputs are acquired from within the respective Länder regions, these linkages do not form across the different media groups. This is due to strong rivalry which exists between these groups and their tendency to isolate themselves from the others. As a consequence of the distribution of the group networks, Munich TV producers have closer contact with Berlin or Leipzig as opposed to Cologne which is the home base of the major competing media group, i.e. RTL-Bertelsmann. Seemingly different local cultures have developed around the two private media groups in Cologne and Munich which are partially grounded in rivalry, and have given rise to scepticism about the each other's activities. Producers in Munich, for instance, described their counterparts in Cologne as relatively arrogant despite the fact that they were involved in low-budget, less creative project work. ${ }^{4}$

\footnotetext{
${ }^{4}$ One producer of a large Munich firm described this tension as follows: "What drives us as a company is that we benefit from the know-how of others. This is why Munich is much more down to earth [than Cologne], I think, because here a profession [in the media business] is more of a normality than in other cities. In Cologne, people think they are stars just because they work for TV and wear fancy RTL $t$-shirts ...”
} 
Overall, our study has provided evidence that there are indeed processes in the Munich film and TV industry cluster which could be referred to as local buzz but information flows and knowledge transfers appear limited to particular circles of people or segments of the industry. Our interviews suggest that these linkages are highly fragmented according to media sector, TV/film genre, media group and location. The result of these communication and interaction patterns is that information flows are selective and opportunities for creative recombination and innovative ideas limited.

\section{International Linkages and Market Access}

Although local networks of communication and interaction are important, the economic success of clusters often depends on the development and maintenance of trans-local pipelines which provide access to international markets and finance (Bathelt, Malmberg and Maskell 2004, Bathelt 2005). Depending on the particular type of film or TV project and the financial support required, projects can involve firms from other German or international media centres. Similar to observations of Grabher (2002b), personal address lists and private cellular phone numbers (i.e. the 'know-who') have become decisive anchor points in the processes of exchanging, distributing and acquiring information. Of course, these networks are not purely local. They have developed over time and are based on the actors' personal experiences and backgrounds. Nonetheless, these networks often have a particular face-to-face history which has helped establish joint interpretative schemes over time (Bathelt, Malmberg and Maskell 2004). In terms of the German film and TV industry, access to markets outside of Germany is most interesting in terms of potential growth opportunities. As will be discussed below, such international linkages and market access are surprisingly weak, however, limiting the inflow of ideas and new contracts. 
In the area of $T V$ production, there are only few linkages with foreign markets, such as those of the public broadcasters with their Austrian, Swiss and French counterparts. The joint French-German TV channel ARTE, located in Strasbourg and Baden-Baden, is an exception. Most linkages are related to joint shows or the exchange of TV formats, such as crime series. The successful licensing of TV programs, such as 'Derrick', a successful crime series which has been dubbed and sold to many countries worldwide, is rare. The establishment of licensing agreements with foreign broadcasters is often not systematically planned in advance. Exceptions have occurred arbitrarily. If such agreements were to be expanded in the future, more TV productions would have to be done in English because there is not much demand for German or dubbed TV formats in other countries. The TV market is primarily viewed as a national market with many 'cultural particularities'. One interviewee emphasized that it is very difficult to sell German formats to other countries. It seemed that the public broadcasters have stopped their efforts to establish international linkages. A leading representative of one broadcaster mentioned that such attempts were made a while ago. However, as he phrased it: "The Brits are too egoistic, the Eastern block has no money, Italy is too chaotic..." Only few co-productions exist which mainly focus on the joint financing of TV formats. The Munich media sector is often not involved in the actual production of joint documentaries and TV films, an activity which is done elsewhere. The representative of one public broadcaster described such co-productions as being difficult because they often involve conflicts due to divergent interests.

Surprisingly, we also did not discover strong initiatives to provide better access to the Eastern European markets through the organization of co-productions or licensing. Such access could be important in the future as the Eastern European media markets have only recently opened up and are likely to grow. Interaction is strongest in the area of studio production and decoration, due to low labour costs in Eastern Europe. In contrast, attempts to attract US and 
other foreign movie productions to Munich have been less successful despite the long history of such endeavours (e.g. productions of Alfred Hitchcock and Luchino Visconti).

Joint international activities in the area of movie production exist but have primarily focused on co-financing. German distributors, for instance, carry a substantial portion of the costs of Hollywood Majors which produce 'blockbuster movies' for global markets (Scott 2002). This tradition of co-financing dates back to the pre-World War II period. As opposed to cofinancing, international co-productions are rare. They sometimes occur when international involvement enables German producers to access additional funds or tax pre-emption as in the case of Canada. A small producer mentioned in this context: "The most important things I get at the moment are the so-called international tax incentives. I have already done a few films in Vancouver and I was quite pleased to film there." Since the 1980s, German movies have occasionally been successful in international markets (e.g. 'Die Blechtrommel', 'Das Boot', 'Lola rennt'). Low-budget, high-profile German movies (so-called Autorenfilm) associated with independent directors, such as Rainer Werner Fassbinder, have also received much attention by international critics but did not sell to a large audience. Despite these successes, there have been no real efforts to engage in co-productions with Hollywood producers. The Hollywood Majors are seemingly not very interested in such cooperation as they do not require external support. Contacts with German producers are typically accomplished through subsidiaries and not the Majors themselves. Such contacts develop, for instance, when US producers want to produce at European sites.

Producers also complained that it is difficult to launch German movies in the US market. Aside from aspects of consumer taste and other cultural factors, the US market seems relatively closed and difficult to access. As one interviewee pointed out, it is difficult for foreign films to receive favourable time slots in the movie theatres without cooperation from 
the Hollywood Majors, despite the forced disintegration of the US film distribution chain after the Paramount antitrust case in 1948 (e.g. Storper and Christopherson 1987). German productions would supposedly be more successful in entering the North American market if they would be able to actively involve US partners in co-financing and/or co-production. Such arrangements under the lead of German producers are, however, virtually non-existent. Contacts with the Hollywood Majors are usually initiated through them and take place under the lead of one of their subsidiaries.

There are some producers within the Munich media industry cluster, however, which have a very strong focus on international co-productions and try to implement international cofinancing arrangements. As one film producer mentioned, networks are primarily established during international festivals and fairs. Co-financing networks encompass partners in the US, Canada, England and Australia, while co-productions primarily take place in Eastern Europe and Canada, due to cost advantages and tax incentives. Because of the difficulties of accessing financial resources in Germany, international productions rarely take place in Munich. One interviewee regretted this because it would block off opportunities for internationalization: "I would have liked to have this big international project here in Bavaria but it failed because the public film fund said that they wouldn't do it. ... The problem was the financing. And regardless of what the conditions are [such as] nice weather and great cafes or other things this is totally irrelevant for me as a producer.”

This leads to a 'global-local dilemma'. Although there are some independent producers which establish creative, technical and financial pipelines with markets in other countries, the Munich cluster does not benefit much from these linkages because it is not possible to establish a local platform for production activities. 
Similar to the trend in studio production and decoration, post-production is increasingly subcontracted to Eastern European low-cost locations. Often, there is no direct connection between the Munich producers and foreign post-production firms. One major German producer, for instance, typically hires Munich firms for post-production activities. At the same time, this producer creates strong cost-cutting pressure which, in turn, stimulates the post-production firms to look out for partners in Eastern Europe. Due to these practices, they strengthen the networks of potential future competitors in Eastern Europe.

The former Werk Group, which had established a large international production network with subsidiaries in many cities and countries (e.g. Frankfurt/Main, London, New York, Los Angeles), is an interesting exception (e.g. Krätke 2002). Due to these linkages, the Werk Group was able to acquire many international contracts, some of which were fulfilled in Munich. Such linkages brought contracts, expertise and growth to the Munich film and TV industry. In 2003, the Group had to declare bankruptcy and was subsequently split up as a consequence of financial problems related to the media crisis. Parts of the former Werk Group still exist as independent post-production firms but are hardly able to establish new international linkages because they do not have enough personnel. As one owner mentioned, they benefit from trans-local pipelines which were established by the former Werk Group and have existed over a longer time period. Overall, most post-production firms interviewed were surprisingly passive with respect to the acquisition of contracts and had few external contacts with customers in other regions or countries.

In general, the results of our research indicate that there are only few international linkages or pipelines which would be able to direct additional contracts, substantial growth, leading international artists and creative ideas to Munich. As mentioned before, the results of this 
structure are stagnation tendencies and dilemmas which have become clearer with the end of the expansion period of private/commercial broadcasters.

\section{Inter-Sectoral Linkages and Additional Finance}

In addition to the lack of trans-local pipelines, inter-sectoral linkages between different segments of the Munich media economy were also identified as being weak in our study. Such linkages have, for instance, become increasingly important in the growth trajectory of the Hollywood media cluster, encouraging the establishment of an integrated entertainment complex (Scott 2002). Munich does not, however, display similar tendencies as will be shown in this section. The tendency of building new linkages between different sectors, such as that between information technology and media (e.g. the digitalization of activities and introduction of new digital products and services) which was observed in Munich in the mid 1990s (van den Berg, Braun and van Winden 2001), has seemingly not developed further.

Most TV productions are financed by German broadcasters, even though different models exist as to how this is done: (a) fully financed productions, (b) combined financing including public film funds or financial resources of production firms, (c) international co-productions (which might have the character of co-financing but are rare), (d) joint financing by several production firms and subsequent sales to broadcasters. The latter option is unlikely to work out in periods of crises when new productions are cut. Public broadcasters have generally suffered from stagnation in their financial budgets. Due to this, some people have suggested that the TV fees paid by viewers should be increased to stimulate additional productions. The effects of this would be unclear though. In the end, it would be a political decision of the broadcasters as to how this money should be spent. Compared to the public segment, private broadcasting services have experienced a drastic cutback in their budgets due to the reduction 
in advertising expenditures. As described above, this has led to a decline in external production contracts and had strong effects throughout the whole production chain (Table 1, Table 2).

Overall, expansion in the entertainment sector has been limited. Firms seemingly do not try to broaden their products and services to other segments of the media industry. This is exemplified by a firm identified in the area of 3D animations with applications in the area of architectural structures. The firm does not intend to enter the advertising, film and TV markets, even though these fields require similar competencies.

Further sources of additional finance are also not well-developed in the Munich region. With the exception of the Bavaria Filmstadt in Geiselgasteig, merchandising activities are underdeveloped. Even successful production firms have a low variety of merchandising products and sell only small quantities of videos or DVDs to individual customers. A problem is, of course, that the merchandising rights are often not in the hands of the production firms. As one interviewee mentioned, it takes 12 years in his case before the licensing rights of contract work shift from the customer to the production firm. But even the broadcasters do not systematically expand and advertise such products. It seems that the development of merchandising is in an infant stage and the potential benefits are widely underestimated. As one interviewee confirmed: "Yes, merchandising has always been one of our biggest weaknesses which I have attempted to address in my discussions with the Association of Producers. The TV companies and contract producers never grant us any rights. We have to give everything away. ... As in the case of the [particular] comedy ... we produce, the ... public broadcaster treats merchandising in a rather unprofessional way. There are some ideas in our house to get things going but the best you can hope for is to find coffee cups with a small logo ... glued to it. Together with our co-producer we attempted to at least retain our internet 
rights in that we said: 'Okay, we will cut part of our production costs and secure our internet rights by creating a website.' These discussions lasted about four months and did not succeed anyway. And again, we had nothing to go with.” Overall, potentials for merchandising or product placement are presently not exploited to a great extent. There is no trend to provide closer linkages between the film and TV industry and other media or manufacturing industries by producing and marketing music, accessories or toys.

As opposed to TV production, film funds and co-financing arrangements with foreign partners are more important in the segment of movie production. Budgets are also much higher than those for TV productions. Although there are substantial film funds available at the European and the Länder levels, most of the movie producers interviewed were particularly concerned about the private film funds in Germany and international market access and funding for their films, particularly with respect to the US market. Although there are numerous private film funds located in Munich, it is hardly possible for local independent filmmakers to access these financial resources. As one producer complained, these funds invest mostly in big Hollywood productions because the rate of return is much higher and more secure than that expected from German films. In 2003, private German media funds amounted to a total of 1.7 billion Euros and 2.5 billion Euros of equity and bonded capital, respectively (Kurp 2005). In Hollywood, this source of financing is also referred to as 'stupid German money' (Kurp 2004). Related to the 'global-local dilemma' mentioned above, this creates a kind of vicious circle: while independent producers in Munich are not able to mobilize enough money for internationally competitive movie productions, local private media funds even strengthen the US Majors, contributing to a growing gap in the availability of financial resources. 
Overall, the success of some German movies in foreign markets has not had much of an effect on the budgetary situation of the production firms. It has not become easier to acquire financial funds, nor has the amount of available funds grown. In short, the argument is that the Munich TV and film industry has not been able to establish strong networks with partners in other countries which were able to pump additional finance and trigger growth in the region. Despite the successes of some German directors and producers in the area of 'disaster movies' in recent years, this is unlikely to change in the near future.

\section{Conclusions: Barriers to Growth in the Munich Film and TV Industry}

\section{Cluster}

This paper uses the case of the Munich film and TV industry cluster to provide evidence that regional growth patterns cannot easily be understood if the underlying structures of social relations are not examined. We call for a relational analysis and understanding of economic action and interaction in spatial perspective. The growth of Munich into a fully-fledged cluster of the film and TV industry was driven by the introduction of private/commercial TV in the mid 1980s and a sound institutional infrastructure which developed from the city's tradition in film production. The development also benefited from national specificities related to language, consumer taste and other cultural factors which created national entry barriers, similar to those in other national TV markets. From the past successes, one would be tempted to project the growth trajectories into the future. This paper argues, however, that the favourable conditions for growth in the Munich film and TV industry cluster in the postWorld War II period have largely overshadowed its existing structural weaknesses. The advertising crisis and the dissolution of the Kirch Group after the turn of the Millennium have served to enhance the structural weaknesses even more. Our observations of the Munich 
media sector, therefore, contrast with those made by van den Berg, Braun and van Winden (2001) in their study. They described the media sector as being very strong, well developed, diversified and modern, conclusions which seem too positive given the structural problems identified in this paper.

Building upon a recently developed buzz-and-pipeline conception of clusters, we argue that a cluster's economic success is not only based on internal networks of communication and producer-user interaction but also depends on a strong external dimension, involving market and technology linkages with actors in other regions and countries. We propose that local interaction and learning are much stronger and durable if they are constantly enriched through feedback and new developments from outside. The particular combination of local buzz and trans-local pipelines is believed to generate a reflexive process of knowledge creation within a cluster, generating enhanced learning capabilities and dynamic growth.

Cluster firms obviously benefit less from local buzz than expected, due to the existence of highly segmented value chains. Although we were able to identify what we refer to as communication islands in different parts of the city, these do not interact intensively with one another and are unable to function as hubs for widespread information transfer. Further, evidence has been presented which shows that linkages with external markets and access to international finance are surprisingly weak, thus limiting the prospects for future economic growth. Actors of all stages of film and TV production appear somewhat passive in acquiring new partners abroad. The existing lack of financial resources seemingly serves to aggravate this situation. Although there are some producers who establish trans-local pipelines in creative, technical and financial fields, the Munich film and TV industry cluster does not benefit much from these linkages. Additional sources of finance, apart from broadcasting 
services and public film funds, are not well-developed. The use of merchandising strategies and the development towards an integrated entertainment complex are also in an infant stage.

Given these structural weaknesses, prospects for creative recombination, new ideas and additional growth impulses in the Munich film and TV industry seem limited. There are, however, chances for institutional renewal related to the dissolution of the rigid networks of the former Kirch Group. Through this, more intensive information and communications flows could occur in the future. This could also become a focus of additional policy initiatives. Further, the effects of stronger internal networks also require that agents strengthen external business relations both with other media locations in Germany and international media centres. Some unexpected successes in the past have shown that this is possible. More vision in the Munich film and TV industry is also needed and creative individuals should share their international networks with other agents in the cluster.

\section{Acknowledgements}

Many thanks are due to numerous individuals who have commented on the ideas put forward in this paper. We would like to thank particularly the three anonymous reviewers and Editors of Environment and Planning A for their comments which helped restructure this paper. Parts of this paper were written during a visit to the Department of Political Science at the University of Toronto in February 2005. We would like to thank Allison Bramwell, John Britton, Meric Gertler, Antoinette Handley, Tad Homer-Dixon, Jeff Kopstein, Rob Vipond and David Wolfe for their thoughts during this visit. A first draft was presented at the Symposium of German Economic Geographers in Rauischholzhausen in April 2005. Here, we received numerous comments for which we would like to thank the participants. Further, we would like to thank Wolfram Bonnet, Sylvia Heling, Andreas Kewes, Marc Sandmüller and 
Christina Weiß for contributing greatly to the discussions in this project and conducting interviews with us, as well as Clare Wiseman for her valuable comments throughout the course of the research process. We also owe Frank Oliver Schultz (Bavaria Filmstudios) and Stefan Vaupel (Preview Production) many thanks for their support and enthusiasm. Last but not least, thanks are due to all interviewees for generously providing us with detailed information about the processes and structures in and behind the scenes of the Munich film and TV industry cluster.

\section{References}

Amin, A. and Cohendet, P. (2004): Architectures of Knowledge: Firms, Capabilities, and Communities. Oxford, New York: Oxford University Press.

Bathelt, H. (2004): Vom 'Rauschen' und 'Pfeifen' in Clustern: Reflexive Informations- und Kommunikationsstrukturen im Unternehmensumfeld (Buzz and pipelines in clusters: reflexive information and communication structures in the firms' milieu). Geographica Helvetica 59: 93-105.

Bathelt, H. (2005): Cluster relations in the media industry: exploring the 'distanced neighbor' paradox in Leipzig. Regional Studies 39: 105-127.

Bathelt, H. (2006): Knowledge-based clusters - multiplier effects and the role of 'buzz' and ‘pipelines'. In Karlsson, C. (ed.): Handbook of Research on Clusters: Theories, Policies and Case Studies. Cheltenham, Northampton, MA: Edward Elgar, forthcoming. 
Bathelt, H., Malmberg, A. and Maskell, P. (2004): Clusters and knowledge: local buzz, global pipelines and the process of knowledge creation. Progress in Human Geography 28: $31-56$.

Bayerisches Landesamt für Statistik und Datenverarbeitung (2006): Sonderauswertung der Umsatzsteuerstatistik im Stadt- und Landkreis München nach Medienbranchen 2000 2004 (Project-Specific Analysis of Tax Revenue Statistics in the Munich Region by Media Branch 2000 - 2004). München.

Biehler, H., Genosko, J., Sargl, M. and Sträter, D. (2003): Standort München Medienwirtschaft und Fahrzeugbau: Regionale Netzwerke und regionaler Arbeitsmarkt als Erfolgsfaktoren (Media Economy and Automobile Production in Munich: Successes Through Regional Networking). Marburg: Schüren.

Bresnahan, T., Gambardella, A. and Saxenian, A. (2001): 'Old economy' inputs for 'new economy' outcomes: cluster formation in the new Silicon Valleys. Industrial and Corporate Change 10: 835-860.

De Laurentis, C., Cooke, P. and Williams, G. (2003): Barriers to the Knowledge Economy New Media Cluster in the Periphery. Paper presented at the Regional Studies Association International Conference on 'Reinventing Regions in the Global Economy', 12 - 15 April, Pisa.

Ernst \& Young (2006): Filmbarometer 2006: Berlin, Hamburg, Köln, Leipzig, München und Rhein/Main: Stimmungen und Trends (Film Barometer 2006: Trends in Berlin, Hamburg, Cologne, Leipzig, Munich and Rhine/Main). München: Ernst \& Young Frankfurter Allgemeine Zeitung (2002): Lange Schatten auf dem Medienstandort München (Dark shadows on the Munich media center). 9 April, p. 16. 
Frankfurter Allgemeine Zeitung (2003a): Kirch Media stößt Unternehmen ab (Kirch Media gets rid of former branches). 4 October, p. 20.

Frankfurter Allgemeine Zeitung (2003b): Sparprogramm in Saban-Sendern (Cost-cutting measures of the Saban broadcasters). 29 October, p. 19.

Frankfurter Rundschau (2002a): Auffanggesellschaft soll den Kern des Kirch-Konzerns retten (Rescue company established to save the core of the Kirch Group). 9 April, p. 9.

Frankfurter Rundschau (2002b): Aufstieg und Fall im Zeitraffer (Rise and decline at fast motion). 9 April, p. 10.

Frankfurter Rundschau (2006a): ProSieben-Sat.1: Kartellamt untersagt Springer-Fusion (ProSieben-Sat.1: Cartel office prohibits Springer merger). 24 January, p. 1.

Frankfurter Rundschau (2006b): Saban startet Auktion (Saban starts auction). 21 October, p. 1.

Grabher, G. (2002a): Cool projects, boring institutions: temporary collaboration in social context. Regional Studies 36: 205-214.

Grabher, G. (2002b): The project ecology of advertising: tasks, talents and teams. Regional Studies 36: 245-262.

Gräf, A. (2005): München in der Krise? Projektorganisation und Wachstumsprobleme in der Film- und Fernsehproduktion - eine mehrdimensionale Clusterstudie (Munich in a State of Crisis? Project Organization and Growth Problems in Film and TV Production - A Multidimensional Cluster Study). SPACES 2005-08 (URL: http://www.uni-marburg.de/geographie/spaces, 20.07.2006). Marburg: Fachbereich Geographie, Universität Marburg. 
Gräf, P. and Matuszis, T. (2001): Medienstandorte: Schwerpunkte und Entwicklungen (German media centers and their development). In: Institut für Länderkunde (eds.): Nationalatlas Bundesrepublik Deutschland: Band 9. Verkehr und Kommunikation. pp. 114-115. Heidelberg, Berlin: Spektrum.

Gräf, P., Hallati, H. and Seiwert, P. (2001): Öffentlich-rechtliche und private Rundfunk- und Fernsehanbieter (Public and private television and broadcasting services in Germany). In: Institut für Länderkunde (eds.): Nationalatlas Bundesrepublik Deutschland: Band 9. Verkehr und Kommunikation. pp. 118-121. Heidelberg, Berlin: Spektrum.

Horak, J. C. (1996): Munich's First Fiction Feature: Die Wahrheit. In: Elsaesser, T. (ed.): A Second Life: German Cinema's First Decade. pp. 86-92. Amsterdam: Amsterdam University Press.

Industrie- und Handelskammer für München und Oberbayern and Landeshauptstadt München (eds.) (2003): Der Medienstandort München (Munich as a Media Location). München.

Jentsch, C. (2004): Projektorganisation in der Frankfurter Werbeindustrie (Project Organization in the Frankfurt Advertising Industry). SPACES 2004-03 (URL: http://www.uni-marburg.de/geographie/spaces, 20.07.2006). Marburg: Fachbereich Geographie, Universität Marburg.

Jentsch, C. and Bathelt, H. (2007): The organizational paradox in advertising and the reconfiguration of project cooperation. Geoforum 38: forthcoming.

Krätke, S. (2002): Medienstadt: Urbane Cluster und globale Zentren der Kulturproduktion (Media Cities: Urban Centers of Cultural Production). Opladen: Leske + Budrich. 
Krätke, S. and Scheuplein, C. (2001): Produktionscluster in Ostdeutschland: Methoden der Identifizierung und Analyse (Production Clusters in East Germany: Methods of Identification and Analysis). Hamburg: VSA.

Kurp, M. (2004): Medienfonds als „Stupid German Money“. Steuersparmodell unterstützt Hollywood statt deutsche Filmmakers (Mediafonds as „Stupid German Money“.Tax Saving Models Support Hollywood Rather Than German Filmmakers. (URL: www.medienmaerkte.de/artikel/kino/040502_filmfonds.html, 20.11.2006).

Kurp, M. (2005): Die größten deutschen Medienkonzerne 2000 (The Largest 200 German Media Firms). (URL: www.medienmaerkte.de, 12.11.2005).

Leborgne, D. and Lipietz, A. (1991): Two social strategies in the production of new industrial spaces. In Benko, G. and Dunford, M. (eds.): Industrial Change and Regional Development: The Transformation of New Industrial Spaces. pp. 27-50. London, New York: Belhaven.

Lloyd, P. E. and Dicken, P. (1972): Location in Space: A Theoretical Approach to Economic Geography. London, New York: Harper \& Row.

Malmberg, A. and Maskell, P. (2002): The elusive concept of localization economies: towards a knowledge-based theory of spatial clustering. Environment and Planning A 34: 429449.

Maskell, P. (2001): Towards a knowledge-based theory of the geographical cluster. Industrial and Corporate Change 10: 921-943.

Mossig, I. (2006): Netzwerke der Kulturökonomie: Lokale Knoten und globale Verflechtungen der Film- und Fernsehindustrie in Deutschland und den USA (Local Nodes and 
Global Linkages of the Film and TV Industry in Germany and the USA). Bielefeld: Transcript.

Nörr, R., Stiefenhofer, A. and Lutz, U. (2004): Auswirkungen von Basel II auf die Filmwirtschaft (The Impact of Basel II on the Film Industry). (URL: www.tv-produzenten.de/downloads/Basel_II.doc, 25.06.2004).

Oinas, P. (1999): Activity-specificity in organizational learning: implications for analysing the role of proximity. GeoJournal 49: 363-372.

Owen-Smith, J. and Powell, W. W. (2004): Knowledge networks as channels and conduits: the effects of spillovers in the Boston biotechnology community. Organization Science 15: 2-21.

Pinch, S., Henry, N., Jenkins, M. and Tallman, S. (2003): From 'industrial districts' to 'knowledge clusters': a model of knowledge dissemination and competitive advantage in industrial agglomerations. Journal of Economic Geography 3: 373-388.

Porter, M. E. (1990): The Competitive Advantage of Nations. New York: Free Press.

Schätzl, L. (1978): Wirtschaftsgeographie 1: Theorie (Economic Geography 1: Theory). Paderborn: Schöningh.

Scott, A. J. (2000): The Cultural Economy of Cities. London, Thousand Oaks, CA: Sage.

Scott, A. J. (2002): A new map of Hollywood: the production and distribution of American motion pictures. Regional Studies 36: 957-976.

Schmitz, H. (2006): Die Grenzen der Vielfalt (The limitations of variety). Frankfurter Rundschau, 17 November, pp. 24-25. 
Storper, M. and Christopherson, S. (1987): Flexible specialization and regional industrial agglomerations: the case of the US motion-picture industry. Annals of the Association of American Geographers 77: 260-282.

Storper, M. and Venables, A. J. (2004): Buzz: face-to-face contact and the urban economy. Journal of Economic Geography 4: 351-370.

Tracey, P. and Clark, G. L. (2003): Alliances, networks and competitive strategy: rethinking clusters of innovation. Growth and Change 34: 1-16.

Uzzi, B. (1997): Social structure and competition in interfirm networks: the paradox of embeddedness. Administrative Science Quarterly 42: 35-67.

van den Berg, L., Braun, E. and van Winden, W. (2001): Growth Clusters in European Metropolitan Cities. A Comparative Analysis of Cluster Dynamics in the Cities of Amsterdam, Eindhoven, Helsinki, Leipzig, Lyons, Manchester, Munich, Rotterdam and Vienna. Aldershot, Burlington, VT: Ashgate.

Vinodrai, T. (2006): Reproducing Toronto's design ecology: career paths, intermediaries, and local labour markets. Economic Geography 82: 237-263. 
Table 1. Number of Establishments in the Munich Film/TV and Advertising Industry, 2000 2004 (Source: Computed from Bayerisches Landesamt für Statistik und Datenverarbeitung 2006)

\begin{tabular}{ccccc}
\hline Media Industry branch & \multicolumn{4}{c}{ Establishments } \\
& $\mathbf{2 0 0 0}$ & $\mathbf{2 0 0 1}$ & $\mathbf{2 0 0 3}$ & $\mathbf{2 0 0 4}$ \\
\hline Broadcasting(1) & 43 & 48 & 54 & 51 \\
Film/TV production/post-production & 953 & 987 & 1,020 & 1,043 \\
Film distribution and other services & 116 & 105 & 110 & 104 \\
News agencies/journalists & 1,391 & 1,409 & 1,494 & 1,647 \\
\hline Subtotal & 2,503 & 2,549 & 2,678 & 2,845 \\
\hline Advertising & 1,980 & 1,979 & 1,973 & 2,084 \\
\hline Total & 4,483 & 4,528 & 4,651 & 4,929 \\
\hline Note: & & & & \\
(1) Public broadcasters are not included. & & & \\
\hline
\end{tabular}


Table 2. Sales in the Munich Film/TV and Advertising Industry, 2000 - 2004 (Source: Computed from Bayerisches Landesamt für Statistik und Datenverarbeitung 2006)

\begin{tabular}{lcccc}
\hline Media Industry Branch & \multicolumn{5}{c}{ Sales in 1,000 EUROs } \\
& $\mathbf{2 0 0 0}$ & $\mathbf{2 0 0 1}$ & $\mathbf{2 0 0 3}$ & $\mathbf{2 0 0 4}$ \\
\hline Broadcasting(1) & $2,687,337$ & $3,475,000^{(2)}$ & $3,352,000$ & $3,457,924$ \\
Film/TV production/post-production & $2,663,976$ & $2,213,868$ & $2,194,874$ & $2,105,908$ \\
Film distribution and other services & $2,536,655$ & $2,626,075$ & 847,298 & 776,819 \\
News agencies/journalists & 123,730 & 134,775 & 128,559 & 130,995 \\
\hline Subtotal & $8,011,698$ & $8,449,718$ & $6,522,731$ & $6,471,646$ \\
\hline Advertising & $2,118,914$ & $1,710,000$ & $1,244,000$ & $1,404,026$ \\
\hline Total & $10,130,612$ & $10,159,718$ & $7,766,731$ & $7,875,672$ \\
\hline & & & & \\
\hline Note: & & & & \\
(1) Public broadcasters are not included. & & & \\
(2) Due to the merger of the private broadcasters ProSieben and Sat.1 into the ProSiebenSat.1 Media AG, \\
sales in Munich's broadcasting sector increased by ca. 850 million Euros in 2001. Prior to 2001, Sat.1 used \\
to be headquartered in Berlin.
\end{tabular}


Table 3. Number of Interviews Conducted in the Munich Film and TV Industry by Actor Group/Branch, 2002 - 2004 (Source: Survey Results)

Interviews conducted

\begin{tabular}{ccc} 
Actor Group/Branch & Number & Share (\%) \\
\hline TV-Station & 5 & 7.7 \\
Production firm & 24 & 36.9 \\
$\begin{array}{c}\text { Post-production/ } \\
\text { service firm }\end{array}$ & 16 & 24.6 \\
Freelancer & 16 & 24.6 \\
Other media institution & 4 & 6.1 \\
\hline Total & 65 & 99.9 \\
\hline
\end{tabular}

Table 4. Number of Interviews Conducted in the Munich Film and TV Industry by Establishment Size, 2002 - 2004 (Source: Survey Results)

\begin{tabular}{ccc}
\hline $\begin{array}{c}\text { Establishment Size } \\
\text { (Employees) }\end{array}$ & Number & Share (\%) \\
\hline $1-10$ & 40 & 61.5 \\
$11-50$ & 11 & 16.9 \\
$50-100$ & 6 & 9.2 \\
$>100$ & 8 & 12.3 \\
\hline Total & 65 & 99.9 \\
\hline
\end{tabular}


Figure 1. Project Organization and Division of Labour in the Production of a Fictional TV Series in the Munich Film and TV Industry (Source: Based on Gräf 2005: 12)

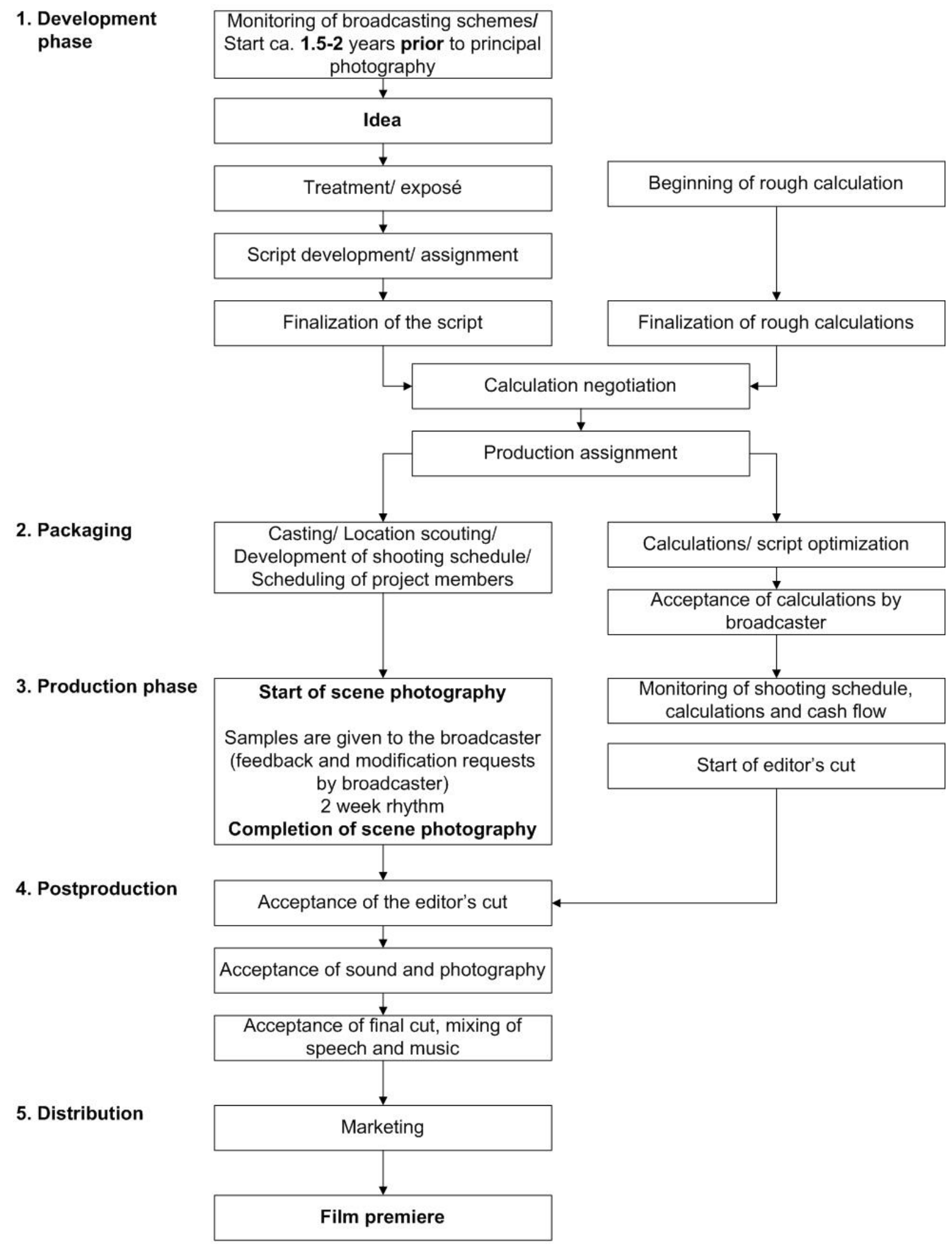


Figure 2. Location of Important Firms and Institutions in the Munich Film and TV Industry, 2006 (Source: Based on Survey Results)

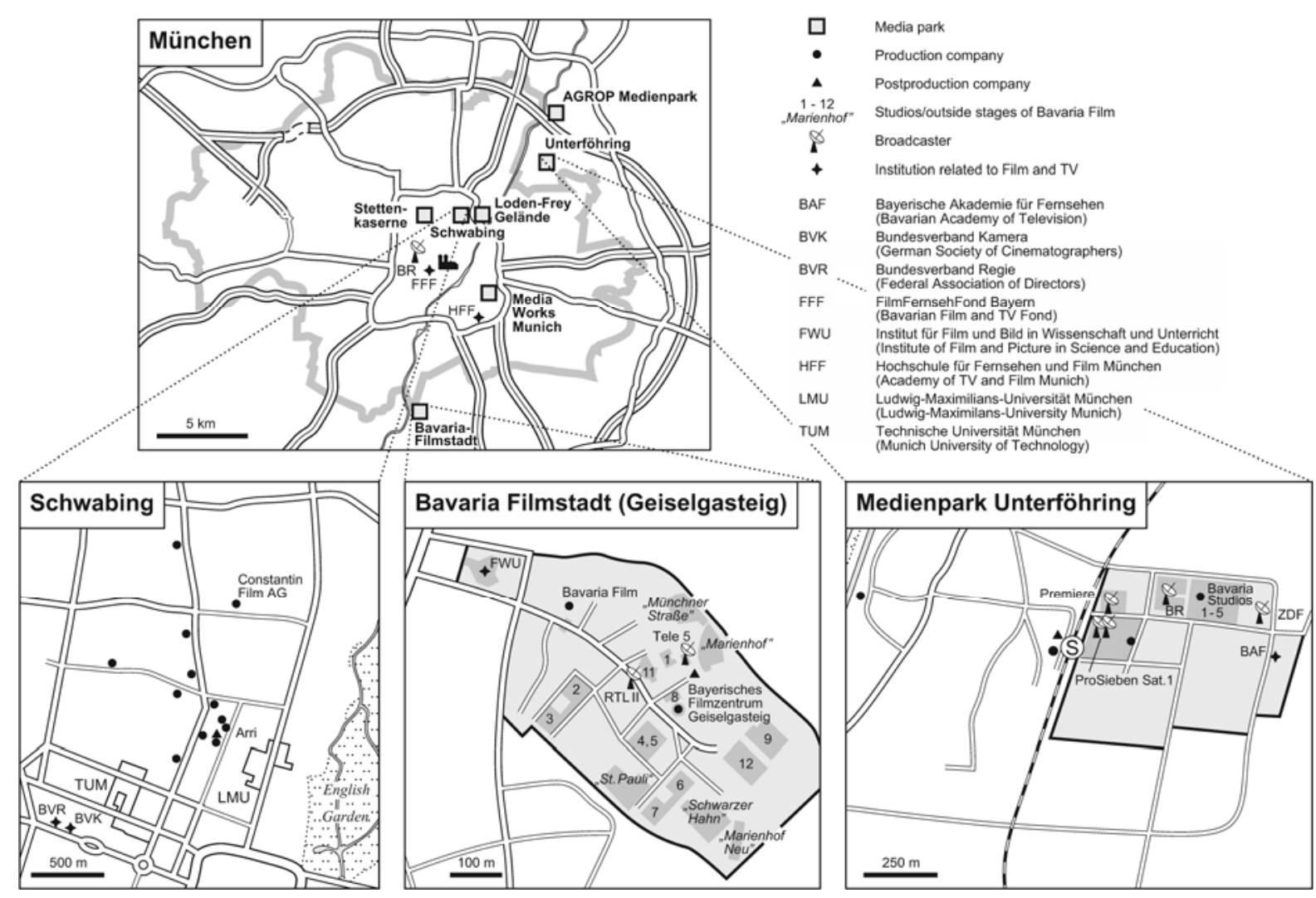

